\title{
Model research of injection of gasoline and E85 into the engine intake pipe
}

\begin{abstract}
The paper describes a simulated injection of $P B 95$ and $E 85$ to an intake pipe. Integrated with a model of an injector, a geometric model of an intake pipe of a diameter that corresponds to real dimensions was developed with AVL FIRE software. Twenty consecutive injections of these types of fuel to the intake pipe were simulated. The studies focused on how the intensity of fuel film formation was impacted by PB 95 and E85 depending on engine speed and the pressure in the intake pipe. The paper provides selected results for several engine operating points.
\end{abstract}

Key words: CFD modeling, fuel film, ethanol

\section{Badania modelowe wtrysku benzyny i paliwa E85 do przewodu dolotowego silnika}

\begin{abstract}
W artykule przedstawiono badania modelowe wtrysku benzyny Pb95 oraz paliwa E85 do przewodu dolotowego silnika. Zastosowano oprogramowanie AVL FIRE. Zbudowano model geometryczny przewodu dolotowego o średnicy odpowiadajacej wymiarami obiektowi rzeczywistemu, wraz z zamontowanym modelem wtryskiwacza. Symulowano 20 kolejnych wtrysków paliwa do przewodu dolotowego. Badano wplyw zastosowanego paliwa na intensywność powstawania filmu paliwowego w zależności od prędkości obrotowej silnika oraz ciśnienia w przewodzie dolotowym. Zamieszczono wybrane wyniki z badań dla kilku punktów pracy silnika.
\end{abstract}

Słowa kluczowe: modelowanie CFD, film paliwowy, etanol

\section{Introduction}

Recently, a considerable growth of interest in substitute and alternative fuels for vehicles has been observed. The growth of oil prices in world markets forces us to search for new fuels that could partly or wholly replace the crude oil based fuels. Recently, a new fuel referred to as Bio85 has appeared in the gas stations. This type of fuel contains $70 \div 85 \%$ ethanol and is an alternative to oil-derivative fuels Application of alcohol-based fuels for fuelling of vehicles may contribute, among others, to a decrease in the exploitation of natural resources (a new source of energy) and a decrease in environmental hazards (lower exhaust emissions). However, the use of ethanol for fuelling of vehicles requires adjustment of the injection and engine control system. FFV (Flexi Fuel Vehicles) adjusted by manufacturers for use of this type of fuel are already available in the Polish market.

Following an injection of fuel in the intake system of the engine appears a harmful phenomenon involving sedimentation of some of the injected fuel on the walls. The fuel creates a fuel film that gradually evaporates and drips into the cylinder with a considerable delay. When a fuel other than gasoline is used the volume and speed of evaporation of the fuel film changes. This phenomenon has to be compensated for in an appropriate way (by determining of the coefficients) in the control algorithm. In order to identify the process of fuel spray and the formation of the fuel film on the engine intake system walls for gasoline and E85 simulation tests were performed with the use of software manufactured by AVL. The influence of alcohol-based fuel on the intensity of the fuel film formation depending on the engine speed and the pressure in the intake pipe was also tested. The distribution and thickness of the fuel film in the engine intake pipe was also analyzed.

\section{Wstęp}

Ostatnio obserwuje się znaczący wzrost zainteresowania zastępczymi i alternatywnymi paliwami do pojazdów samochodowych. Wzrost cen ropy naftowej na rynkach światowych skłania do poszukiwania nowych paliw, które częściowo lub całkowicie zastąpiłyby paliwa pochodzące z przeróbki ropy naftowej. Obecnie na stacjach benzynowych pojawiło się nowe paliwo pod nazwą Bio85. Paliwo to zawiera $70 \div 85 \%$ etanolu i stanowi rozwiązanie alternatywne dla paliw ropopochodnych. Zastosowanie paliw alkoholowych do zasilania pojazdów samochodowych może przyczynić się między innymi do zmniejszenia wykorzystania zasobów naturalnych (nowe źródło energii) oraz zmniejszenia zagrożenia środowiska (mniejsza emisja substancji szkodliwych). Zastosowanie etanolu do zasilania pojazdów wymaga jednak przystosowania do tego układu wtryskowego oraz układu sterowania. Na polskim rynku są już dostępne pojazdy FFV (Flexi Fuel Vehicles) przystosowane przez producentów do zasilania tego typu paliwem.

Po wtrysku paliwa w układzie dolotowym silnika powstaje szkodliwe zjawisko osadzania się na ściankach części wtryśniętego paliwa. Paliwo tworzy tam tzw. film paliwowy stopniowo parujący i ściekający do cylindra ze znacznym opóźnieniem. Przy zastosowaniu paliwa o innych właściwościach niż benzyna występuje zmiana wielkości i szybkości parowania filmu paliwowego. Zjawisko to musi być kompensowane w odpowiedni sposób (wyznaczonymi współczynnikami) w algorytmie sterującym. W celu identyfikacji procesu tworzenia strugi paliwa oraz powstawania filmu paliwowego na ściankach układu dolotowego silnika dla benzyny oraz E85 przeprowadzono badania symulacyjne z wykorzystaniem oprogramowania firmy AVL. Badano 
Modeling of physical phenomena occurring in a diesel engine is today very common [2-4]. Solving complex problems is possible thanks to a technique referred to as numerical fluid mechanics. By discretization of the analyzed volume and division into cells of infinite volume and thanks to the numerical solution of partial differential equations it is possible to determine approximate values of pressure gradients, temperatures or flow speeds of compressive factor. Most of the contemporary CFD programs are based on Navier-Stokes' equations describing the principle of behavior of mass, momentum and energy of a moving fluid and, then discretizing the same using the method of finite elements, finite volumes of finite differences. The use of the software also enables conducting simulation tests of flows, in which chemical reactions or combustion processes occur, flows through porous structures, flows of Newton's fluids or non-Newton's fluids and simulation of fluid structure interaction.

\section{The model of intake pipe}

The model of intake pipe was developed in Workflow composed of an intake pipe model and an injector model. The diameter of the intake pipe and the injector dimensions object. In order to eliminate discontinuity in geometry and ensure the required accuracy of calculations, the correctness of the developed grid was verified. A cell type referred to as Hexahedron was used for the construction of the model. Finally, the model included 31500 cells (Fig. 1). This level of geometrical discretization ensured the required accuracy of calculations and simultaneous shortening of the period of calculations. Manager module of AVL FIRE program. The model is were determined based on the measurements of an actual

wpływ paliwa alkoholowego na intensywność powstawania filmu paliwowego w zależności od prędkości obrotowej silnika oraz ciśnienia w przewodzie dolotowym. Analizowano rozkład i grubość filmu paliwowego w przewodzie dolotowym silnika.

Modelowanie zjawisk fizycznych, jakie zachodzą w silniku spalinowym jest obecnie bardzo rozpowszechnione [24]. Rozwiązywanie złożonych zagadnień możliwe jest dzięki technice określanej jako numeryczna mechanika płynów. Przez dyskretyzację analizowanej objętości oraz podział na komórki o skończonej objętości i dzięki numerycznemu rozwiązaniu cząstkowych równań różniczkowych możliwe jest przybliżone wyznaczenie gradientów ciśnień, temperatur lub prędkości przepływu czynnika ściśliwego. Większość współczesnych programów CFD bazuje na równaniach $\mathrm{Na}$ viera-Stokesa, opisujących zasadę zachowania masy, pędu i energii dla poruszającego się płynu, a następnie dyskretyzuje je za pomocą metody elementów skończonych, metody objętości skończonych lub metody różnic skończonych. Zastosowane oprogramowanie umożliwia także prowadzenie badań symulacyjnych przepływów, w których występują reakcje chemiczne lub procesy spalania, przepływów przez struktury porowate, przepływów płynów newtonowskich lub nienewtonowskich oraz symulację interakcji płyn-ciało stałe (Fluid Structure Interaction).

\section{Model przewodu dolotowego}

Model przewodu dolotowego opracowano w module Workflow Manager programu AVL FIRE. Model złożony jest $\mathrm{z}$ modelu przewodu dolotowego oraz z modelu wtryskiwacza. Średnicę przewodu dolotowego oraz wymiary wtryskiwacza określono na podstawie pomiarów rzeczywistego obiektu badawczego. W celu wyeliminowania nieciągłości w geometrii oraz zapewnienia wymaganej dokładności obliczeń wykonano weryfikację poprawności opracowanej siatki. Do budowy modelu zastosowano jeden typ komórki o nazwie Hexahedron. Ostatecznie model składał się z 31500 komórek (rys. 1). Taki poziom dyskretyzacji geometrycznej zapewnił wymaganą dokładność obliczeń przy jednoczesnym skróceniu czasu obliczeń.

$\mathrm{Z}$ uwagi na występowanie przepływu burzliwego niezbędne było zdefiniowanie odpowiedniego modelu turbulencji. Podczas obliczeń zastosowano model k-zeta-f dla przepływów turbulentnych. Wybór ten był

Due to the occurrence of a violent flow, it was necessary to define an appropriate model of turbulence. The k-zeta-f model was used for turbulent flows. This choice was determined by analysis of the literature related to simulation tests [1]. AVL FIRE Wall Film model was also used for the determination of the distribution of fuel in the intake pipe and the determination of the intensity of evaporation of the fuel from the film. The calculations were performed with the assumption of a model of density of an ideal gas, where density was determined by the function of pressure and temperature. The flow of fluid was defined as a compressive flow. podyktowany analizą literatury dotyczącej badań symulacyjnych [1]. Zastosowano także moduł AVL FIRE Wall Film do określenia rozkładu paliwa w przewodzie dolotowym oraz określenia intensywności parowania paliwa z filmu. Obliczenia prowadzono przy założeniu modelu gęstości gazu idealnego, gdzie gęstość została określona funkcją ciśnienia i temperatury. Przepływ płynu zdefiniowano jako ściśliwy.

Warunki początkowe dla powietrza:

- gęstość w warunkach normalnych $1,19 \mathrm{~kg} / \mathrm{m}^{3}$,

- temperatura $30^{\circ} \mathrm{C}$,

- energia kinetyczna turbulencji $0,5 \mathrm{~m}^{2} / \mathrm{s}^{2}$, 
Initial conditions for the air:

- density in normal conditions: $1.19 \mathrm{~kg} / \mathrm{m}^{3}$,

- temperature: $30^{\circ} \mathrm{C}$,

- kinetic energy of turbulence: $0.5 \mathrm{~m}^{2} / \mathrm{s}^{2}$,

- scale of turbulence: $0.003588 \mathrm{~m}$,

- turbulence dissipation speed: $16.1873 \mathrm{~m}^{2} / \mathrm{s}^{3}$.

The tests assumed $\mathrm{Pb} 95$ as fuel and a mixture of ethanol and gasoline (E85 biofuel) with their physical and chemical properties available in the program library. The fuel temperature of $50{ }^{\circ} \mathrm{C}$ was assumed. The fuel was dosed into the intake pipe with the use of an injector model with its shape geometry and dimensions corresponding to the original injector. The injection was made in a stepwise function depending on the fuel injection time ensuring constant output during the entire injection process. The diameter of the intake pipe was $0.036 \mathrm{~m}$. In order to determine the mass of the injected fuel and the mass of air in the intake pipe, identification tests were made with respect to a real object. The obtained results constituted conditions precedent to the developed intake pipe model.

\section{The plan of experiment}

Simulation tests were performed in eight test points for the range of engine speeds from $1500 \mathrm{rpm}$ to $3900 \mathrm{rpm}$ and pressure in the intake pipe of up to $37 \mathrm{kPa}$ to $85 \mathrm{kPa}$. Due to the fact that simulation calculations are time-consuming a calculation step of every $5{ }^{\circ} \mathrm{CA}$ was applied. The simulation process involved twenty consecutive fuel injections into the intake pipe, which allowed the fuel film mass to stabilize in the intake pipe in every test point.

\section{Results of simulation tests}

As a result of the performed simulation tests the authors obtained the distribution and the thickness of the fuel film in the intake pipe following the injection of gasoline and E85 biofuel depending on the engine speed and pressure in the intake pipe. Figure 2 presents a visualization of the fuel injection into the intake pipe for the test point $n=3900$ $\mathrm{rpm}$ and the pressure in the intake pipe of $\mathrm{p}_{\mathrm{d}}=85 \mathrm{kPa}$. The results of the simulation tests presented in Fig. $3-10$ allows examining the distribution and thickness of the fuel film in the intake pipe. Due to the need of appropriate visualization and interpretation of the simulation test results a different scale of concentration was assumed for every test point.

\section{The analysis of simulation test results}

Figure 2 presents an example visualization of the fuel injection into the intake pipe for the engine speed of 3900 rpm and the pressure in the intake pipe $85 \mathrm{kPa}$. From the very beginning of the injection the fuel spray is atomized. Fuel drops are distributed in the intake pipe creating a conical aerosol. After the crankshaft angle of approx. $60{ }^{\circ} \mathrm{CA}$ the atomized fuel hits the bottom wall of the pipe. Nearly the entire dose of the injected fuel reaches the wall. The fuel film formation is accompanied by aerodynamic forces of airflow. Flowing air causes dislocation of the fuel film in the direction of the intake valve and breaking of the same into smaller fragments.
- skala turbulencji $0,003588 \mathrm{~m}$,

- szybkość dyssypacji turbulencji 16,1873 $\mathrm{m}^{2} / \mathrm{s}^{3}$.

$\mathrm{W}$ badaniach jako paliwo przyjęto benzynę $\mathrm{Pb} 95$ oraz mieszankę alkoholu etylowego i benzyny (biopaliwo E85), których właściwości fizykochemiczne dostępne są w bibliotece programu. Przyjęto temperaturę paliwa równą $50{ }^{\circ} \mathrm{C}$. Paliwo dozowane jest do przewodu dolotowego za pomocą modelu wtryskiwacza, którego geometria odpowiada kształtem i wymiarami oryginalnemu wtryskiwaczowi. Wtrysk realizowano funkcją skokową w zależności od czasu wtrysku paliwa, zapewniając stały wydatek w czasie całego procesu wtrysku. Średnica przewodu dolotowego wynosiła 0,036 m. W celu określenia masy wtryskiwanego paliwa oraz masy powietrza $\mathrm{w}$ przewodzie dolotowym wykonano badania identyfikacyjne na obiekcie rzeczywistym. Uzyskane wyniki stanowią warunki wstępne do opracowanego modelu przewodu dolotowego.

\section{Plan eksperymentu}

Badania symulacyjne wykonano w ośmiu punktach badawczych dla zakresu prędkości obrotowych od 1500 $\mathrm{obr} / \mathrm{min}$ do $3900 \mathrm{obr} / \mathrm{min}$ oraz ciśnienia w przewodzie dolotowym od $37 \mathrm{kPa}$ do $85 \mathrm{kPa}$. Ze względu na czasochłonność obliczeń symulacyjnych zastosowano krok obliczeniowy co $5{ }^{\circ} \mathrm{OWK}$. W procesie symulacyjnym realizowano dwadzieścia kolejnych wtrysków paliwa do przewodu dolotowego, co pozwoliło na ustabilizowanie się masy filmu paliwowego w przewodzie dolotowym w każdym punkcie badawczym.

\section{Wyniki badań symulacyjnych}

W rezultacie przeprowadzonych badań symulacyjnych uzyskano rozkład i grubość filmu paliwowego w przewodzie dolotowym po wtrysku benzyny i biopaliwa E85 w zależności od prędkości obrotowej silnika i ciśnienia w przewodzie dolotowym. Na rysunku 2 przedstawiono wizualizację wtrysku paliwa do przewodu dolotowego dla punktu badawczego $\mathrm{n}=3900 \mathrm{obr} / \mathrm{min}$ i ciśnienia $\mathrm{w}$ przewodzie dolotowym $\mathrm{p}_{\mathrm{d}}=$ $=85 \mathrm{kPa}$. Wyniki z badań symulacyjnych przedstawione na rysunkach 3 - 10 pozwalają na zbadanie rozkładu i grubości filmu paliwowego w przewodzie dolotowym. Ze względu na potrzebę właściwej wizualizacji i interpretacji wyników badań symulacyjnych, dla każdego punktu badawczego przyjęto inną skalę koncentracji.

\section{Analiza wyników badań symulacyjnych}

Na rysunku 2 przedstawiono przykładową wizualizację wtrysku paliwa do przewodu dolotowego dla prędkości obrotowej $3900 \mathrm{obr} / \mathrm{min}$ i dla ciśnienia $85 \mathrm{kPa}$. Już od początku inicjacji wtrysku następuje atomizowanie się strugi paliwa. Krople paliwa rozprzestrzeniają się w przewodzie dolotowym, tworząc stożkowy kształt aerozolu. Po czasie obrotu wału korbowego około $60^{\circ} \mathrm{OWK}$ zatomizowane paliwo uderza o dolną ściankę przewodu. Niemalże cała dawka wtryśniętego paliwa dociera do ścianki. Powstaniu filmu paliwowego towarzyszą siły aerodynamiczne przepływu powietrza. Przepływające powietrze powoduje przemieszczanie się filmu paliwowego w kierunku zaworu dolotowego oraz jego rozerwanie na mniejsze fragmenty. 
$20^{\circ}$ C.A.

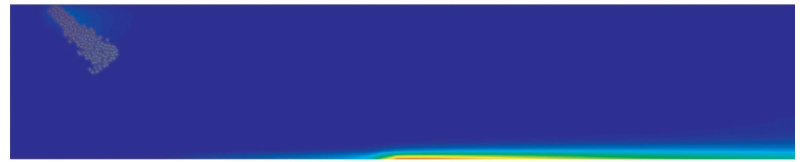

$40^{\circ}$ C.A.

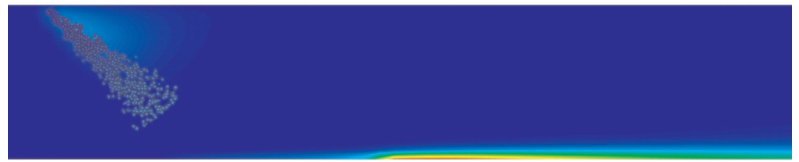

$60^{\circ}$ C.A.

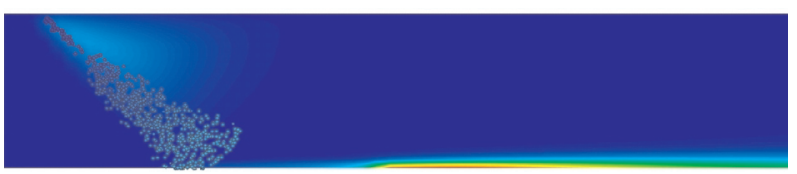

$80^{\circ}$ C.A

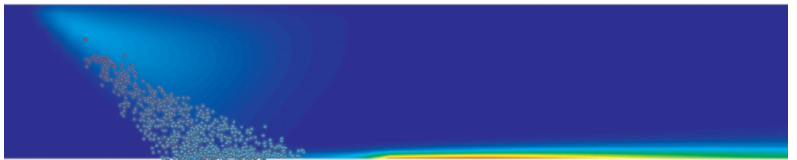

$100^{\circ}$ C.A.

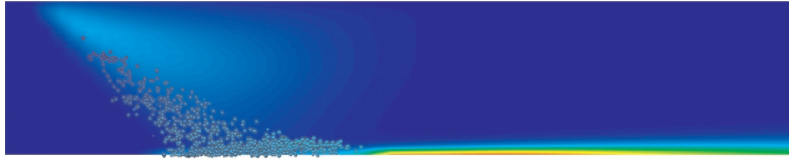

$120^{\circ}$ C.A.

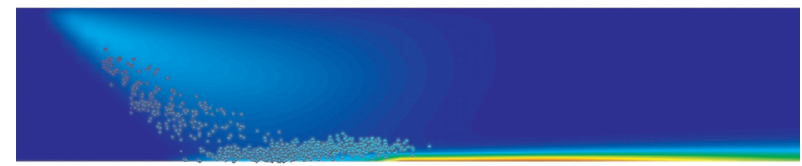

$140^{\circ}$ C.A.

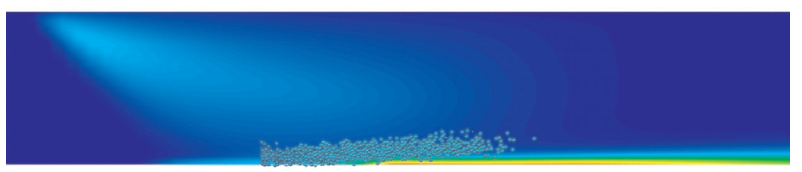

$160^{\circ}$ C.A.

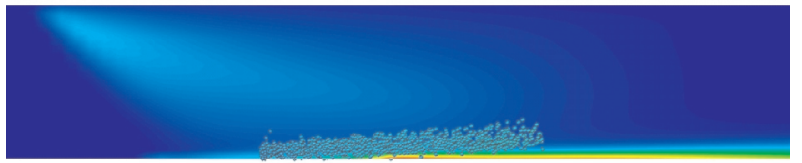

Fig. 2. Visualization of fuel injection into the intake pipe for the test point $\mathrm{n}=3900 \mathrm{rpm}$ and $\mathrm{p}_{\mathrm{d}}=85 \mathrm{kPa}$

Rys. 2. Wizualizacja wtrysku paliwa do przewodu dolotowego dla punktu badawczego $n=3900 \mathrm{obr} / \mathrm{min}$ oraz $p_{d}=85 \mathrm{kPa}$

$\mathrm{Pb} 95$

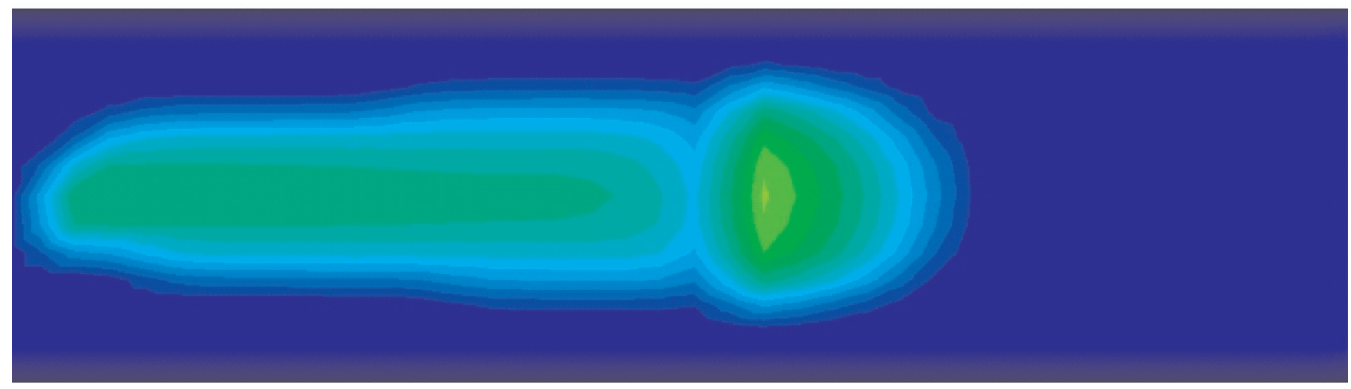

E85
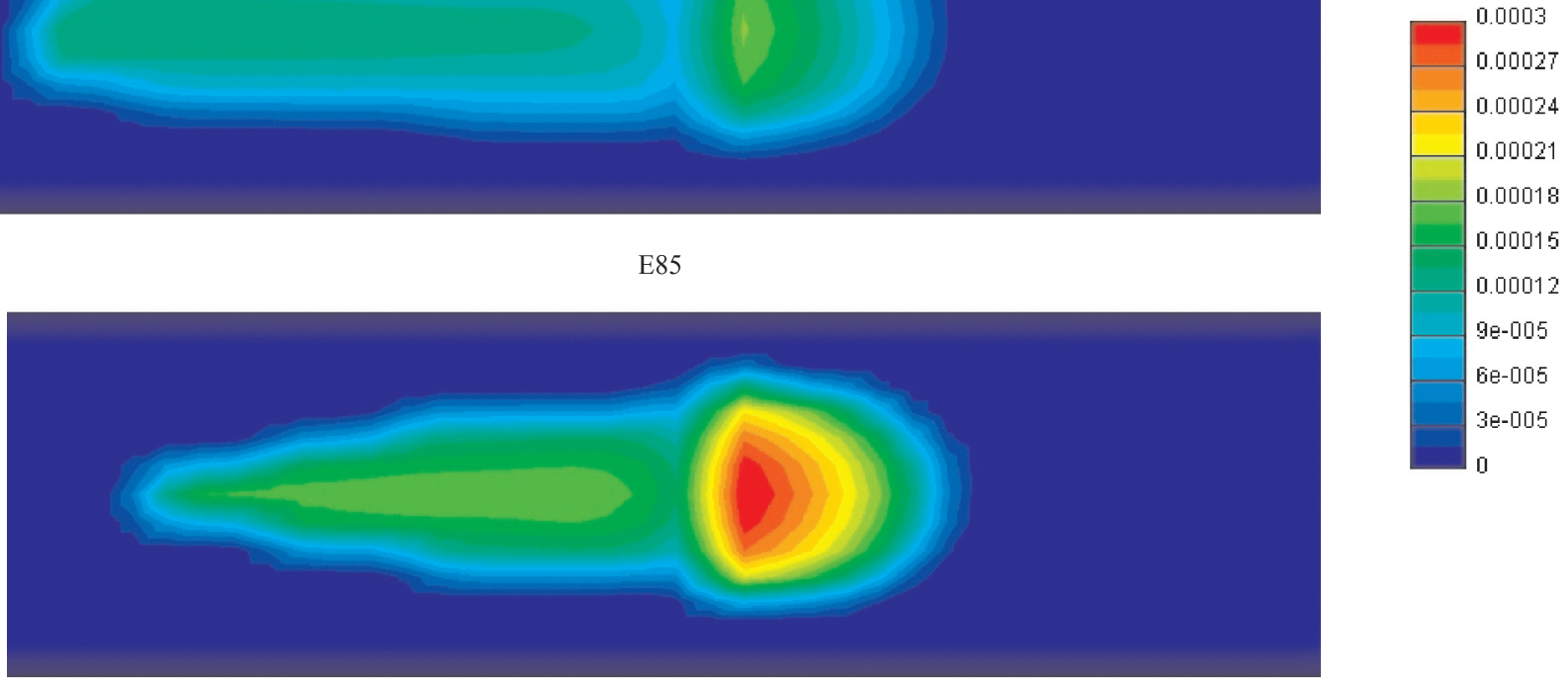

Fig. 3. Distribution and thickness of the fuel film in the intake pipe during the simulation of the feeding of gasoline and E85 biofuel for the engine speed of $3900 \mathrm{rpm}$ and the pressure of $85 \mathrm{kPa}$ in the intake pipe

Rys. 3. Rozkład i grubość filmu paliwowego w przewodzie dolotowym podczas symulacji zasilania benzyna i biopaliwem E85 dla prędkości obrotowej silnika 3900 obr/min i ciśnienia w przewodzie dolotowym $85 \mathrm{kPa}$ 
$\mathrm{Pb} 95$

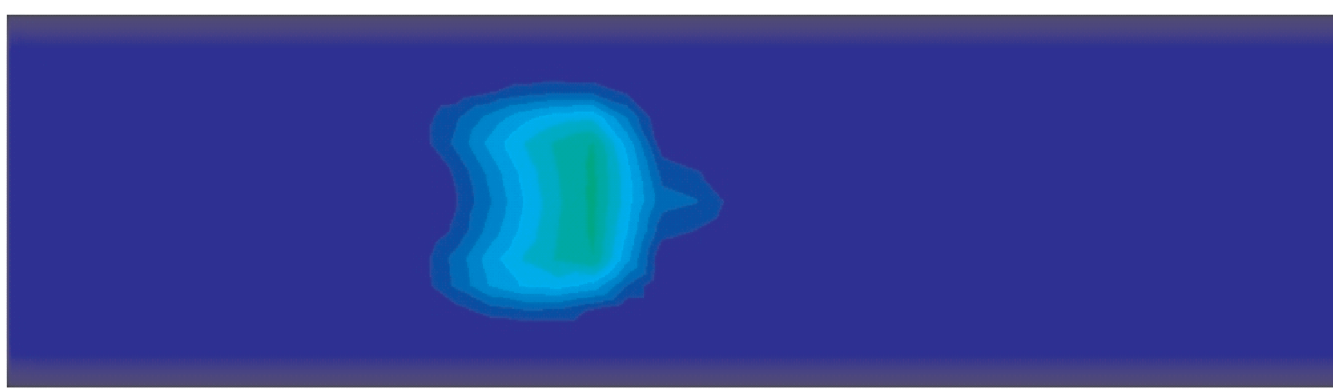

E85
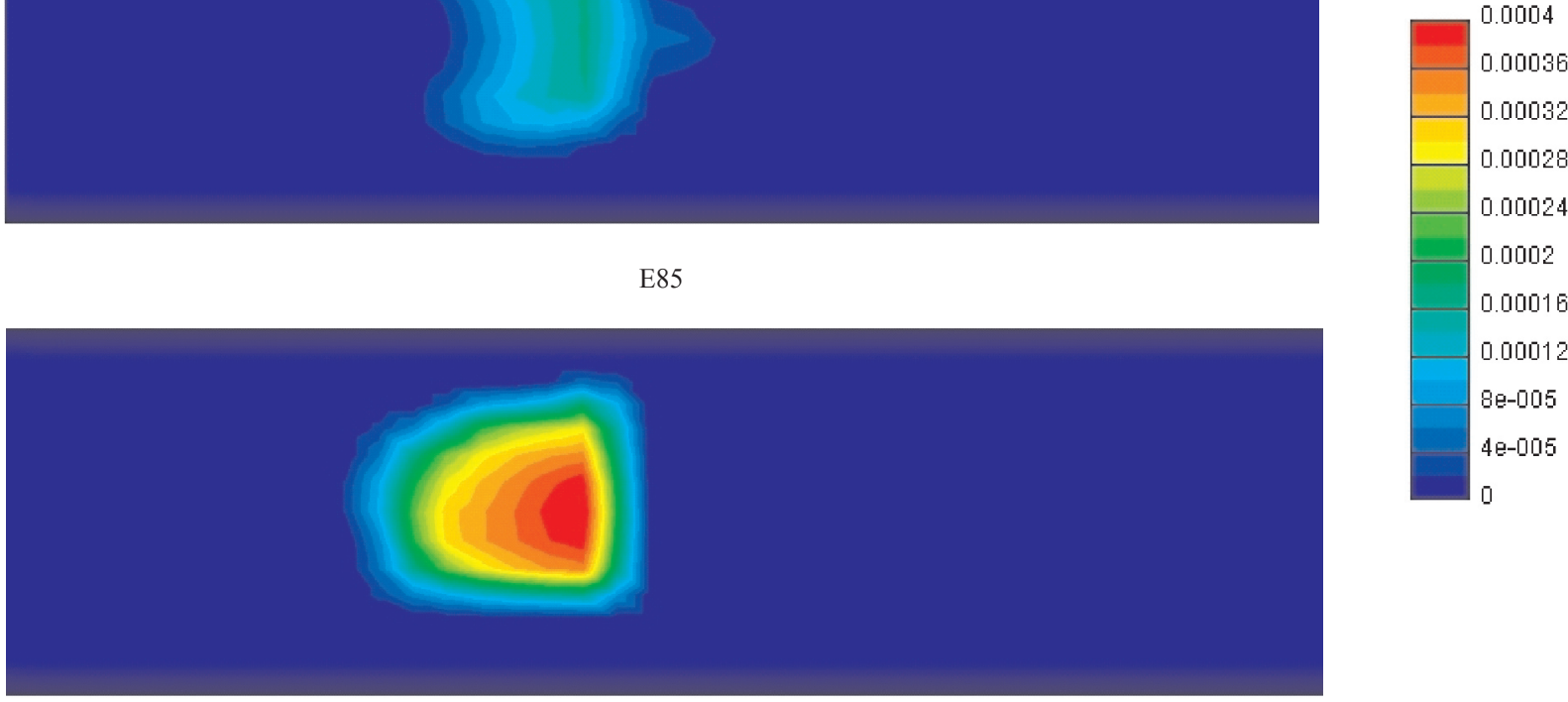

Fig. 4. Distribution and thickness of the fuel film in the intake pipe during the simulation of the feeding of gasoline and E85 biofuel for the engine speed of $1900 \mathrm{rpm}$ and the pressure of $45 \mathrm{kPa}$ in the intake pipe

Rys. 4. Rozklad i grubość filmu paliwowego w przewodzie dolotowym podczas symulacji zasilania benzyna i biopaliwem E85 dla prędkości obrotowej silnika 1900 obr/min i ciśnienia w przewodzie dolotowym $45 \mathrm{kPa}$

$\mathrm{Pb} 95$

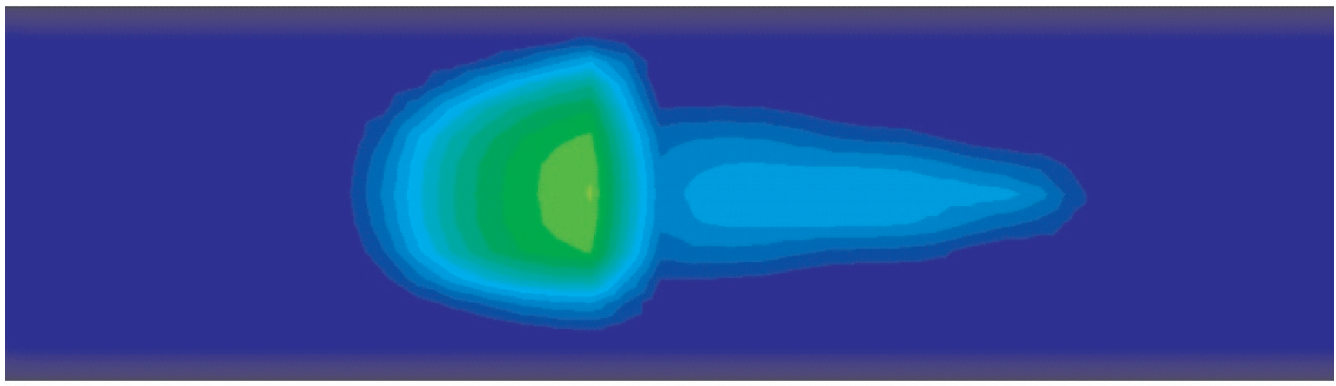

E85
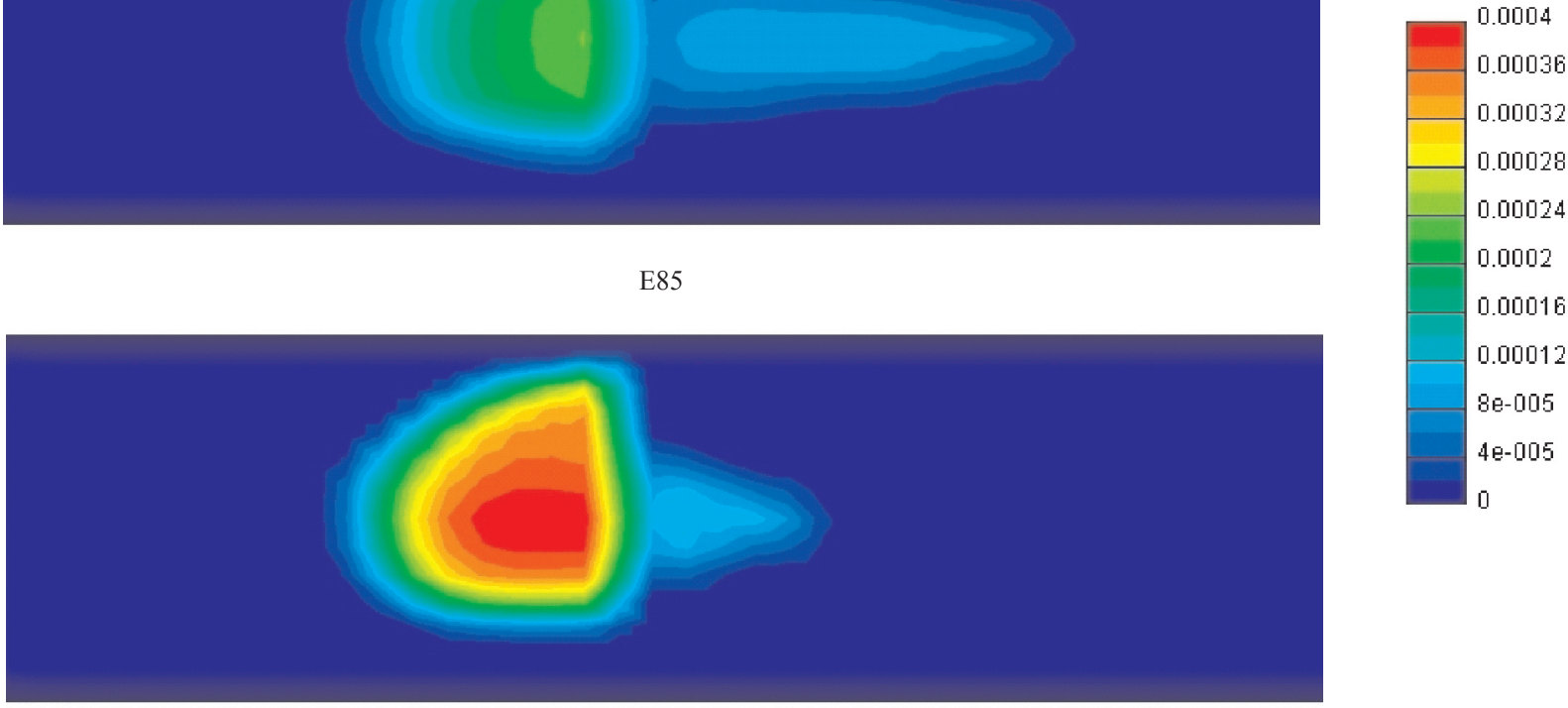

Fig. 5. Distribution and thickness of the fuel film in the intake pipe during the simulation of the feeding of gasoline and E85 biofuel for the engine speed of $1900 \mathrm{rpm}$ and the pressure of $85 \mathrm{kPa}$ in the intake pipe

Rys. 5. Rozkład i grubość filmu paliwowego w przewodzie dolotowym podczas symulacji zasilania benzyna i biopaliwem E85 dla prędkości obrotowej silnika 1900 obr/min i ciśnienia w przewodzie dolotowym $85 \mathrm{kPa}$ 


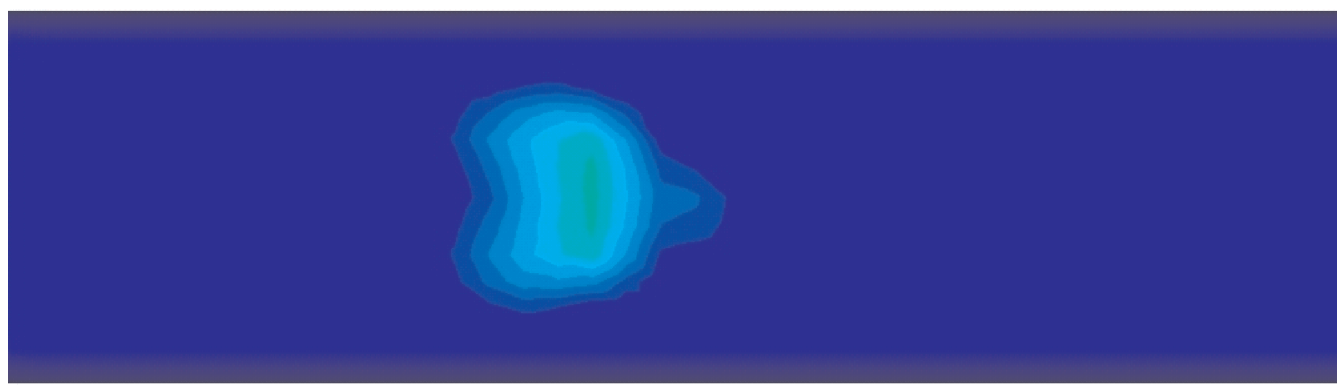

E85
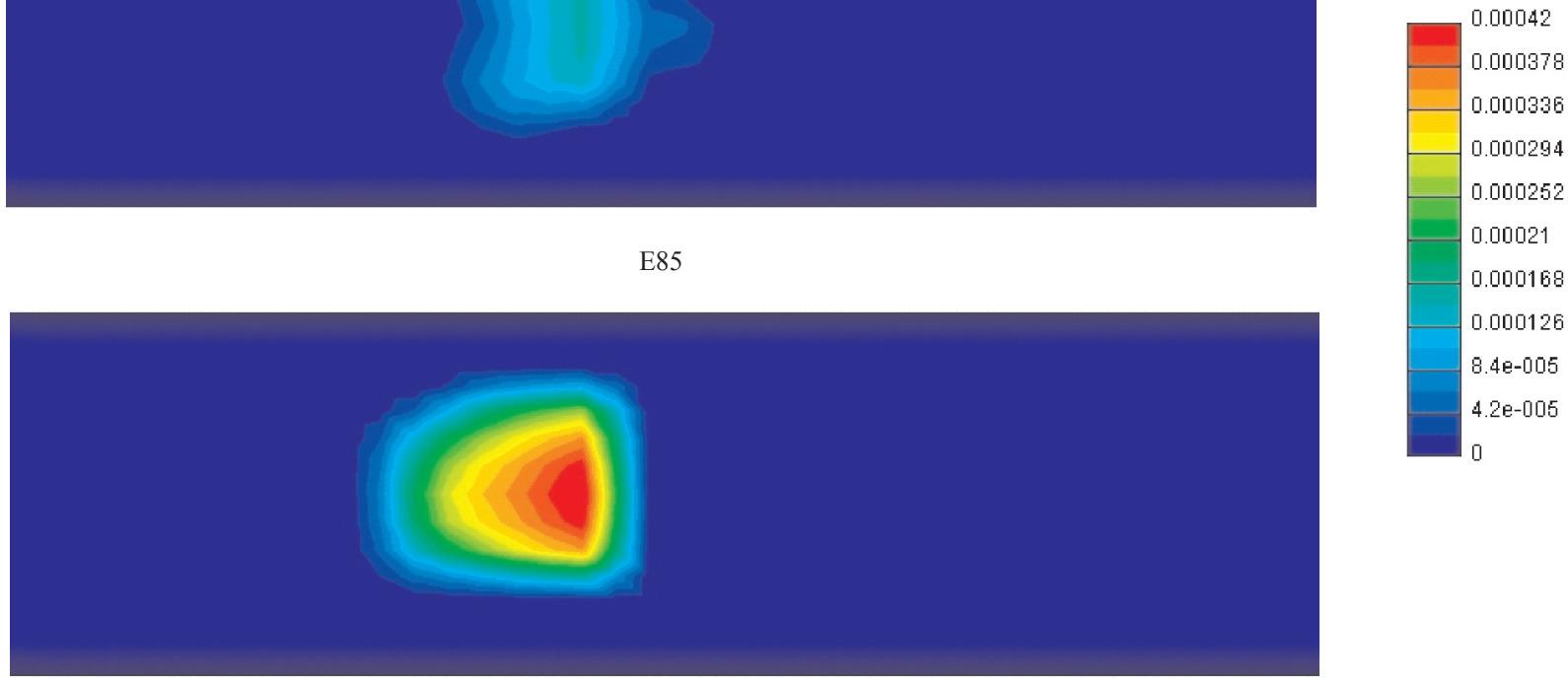

Fig. 6. Distribution and thickness of the fuel film in the intake pipe during the simulation of the feeding of gasoline and E85 biofuel for the engine speed of $2900 \mathrm{rpm}$ and the pressure of $37 \mathrm{kPa}$ in the intake pipe

Rys. 6. Rozkład i grubość filmu paliwowego w przewodzie dolotowym podczas symulacji zasilania benzyna i biopaliwem E85 dla prędkości obrotowej silnika 2900 obr/min i ciśnienia w przewodzie dolotowym $37 \mathrm{kPa}$

$\mathrm{Pb} 95$

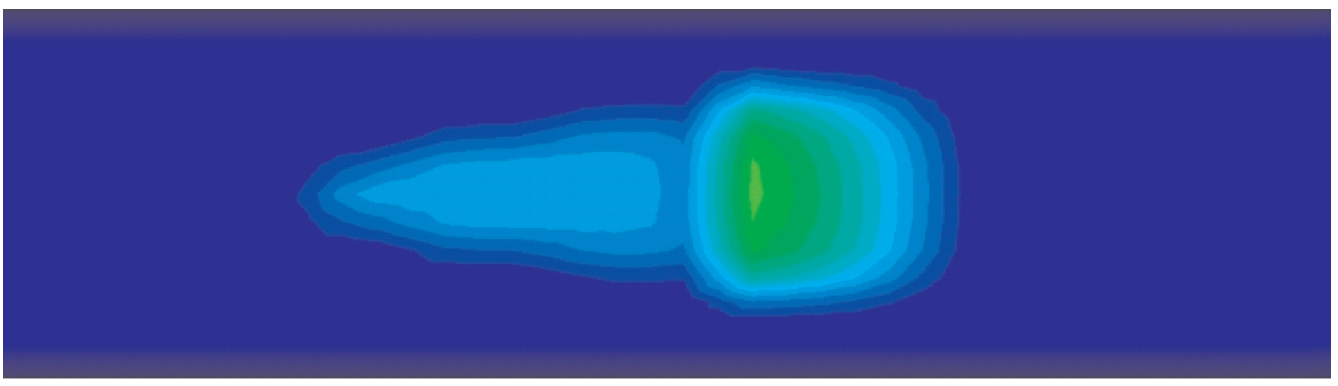

E85
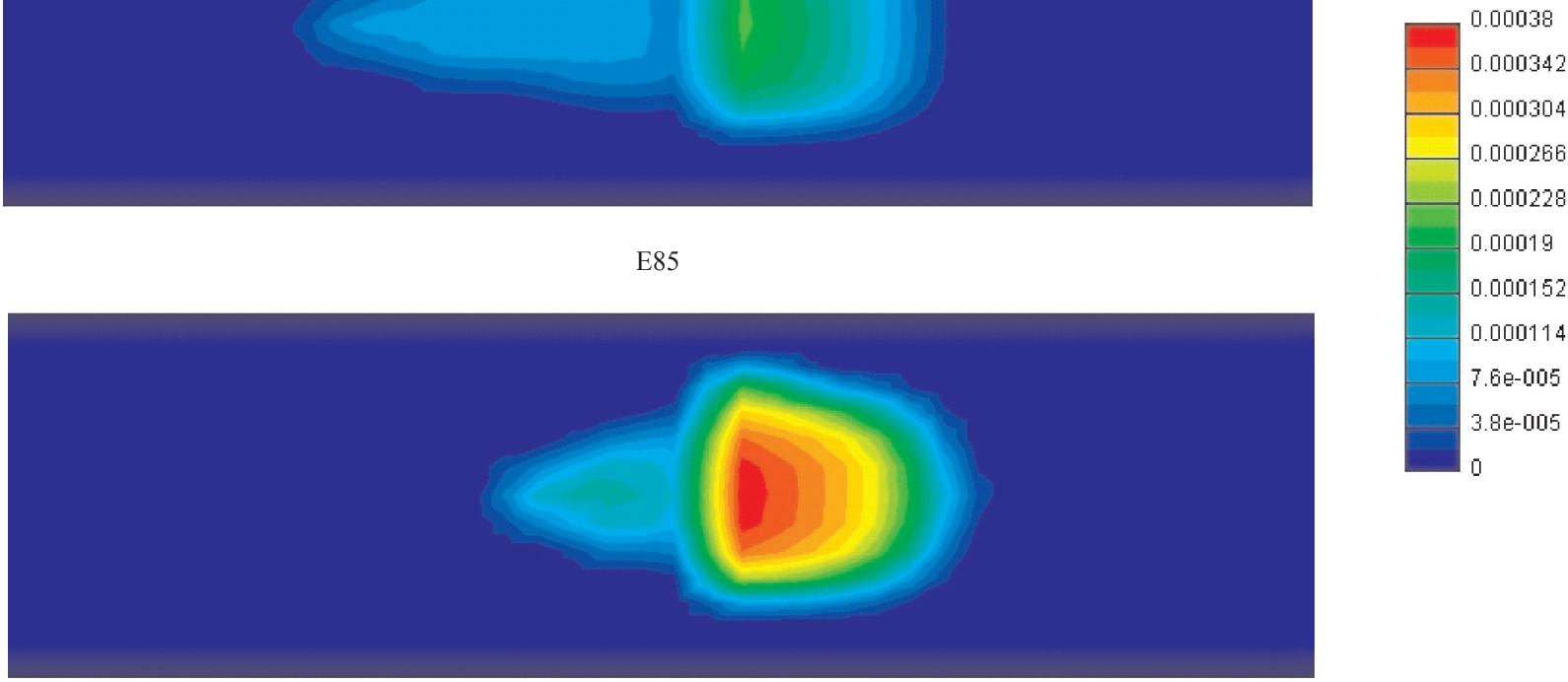

Fig. 7. Distribution and thickness of the fuel film in the intake pipe during the simulation of the feeding of gasoline and E85 biofuel for the engine speed of $2900 \mathrm{rpm}$ and the pressure of $65 \mathrm{kPa}$ in the intake pipe

Rys. 7. Rozkład i grubość filmu paliwowego w przewodzie dolotowym podczas symulacji zasilania benzyna i biopaliwem E85 dla prędkości obrotowej silnika 2900 obr/min i ciśnienia w przewodzie dolotowym $65 \mathrm{kPa}$ 
$\mathrm{Pb} 95$
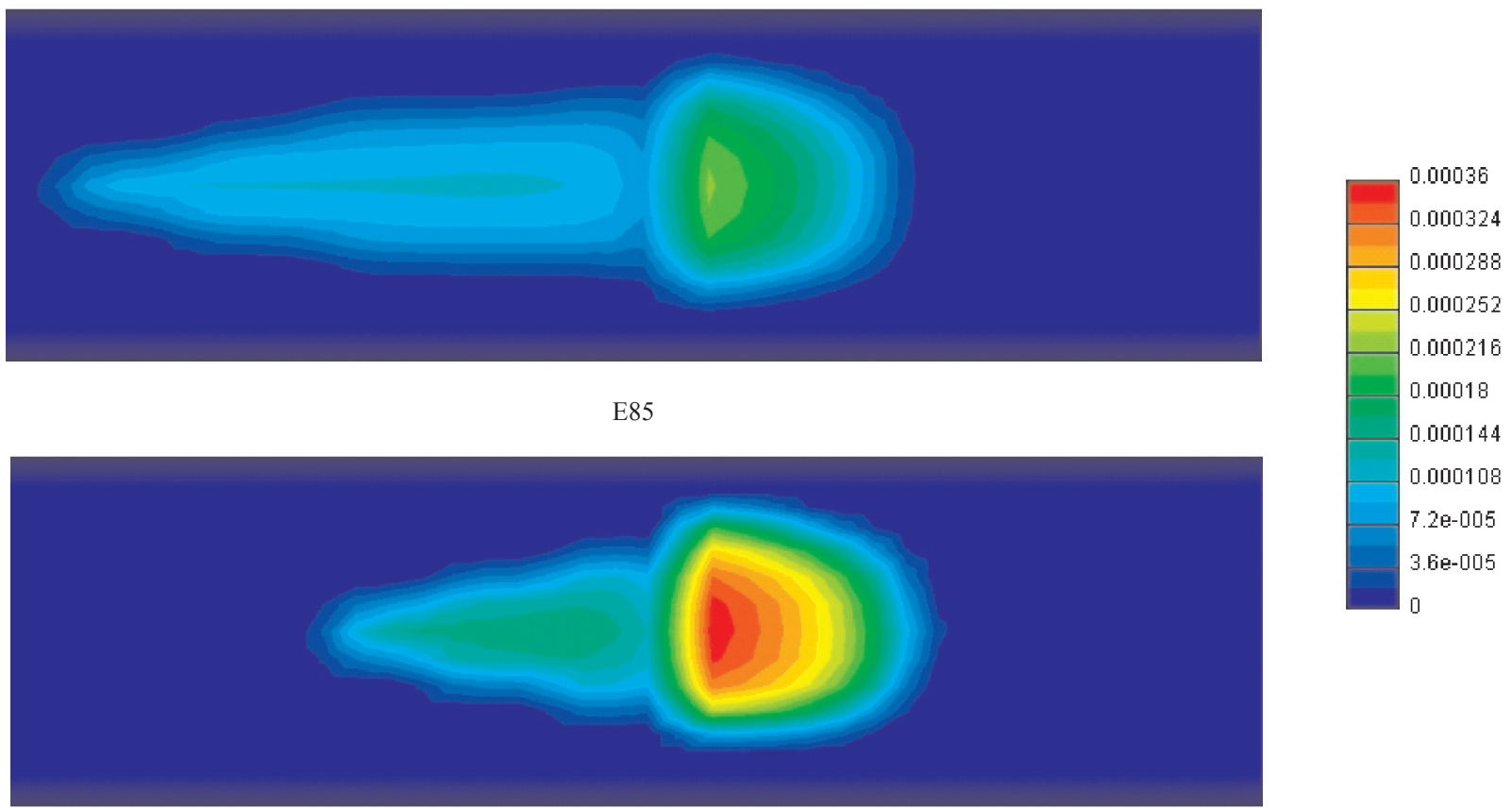

\section{E85}

Fig. 8. Distribution and thickness of the fuel film in the intake pipe during the simulation of the feeding of gasoline and E85 biofuel for the engine speed of $2900 \mathrm{rpm}$ and the pressure of $85 \mathrm{kPa}$ in the intake pipe

Rys. 8. Rozkład i grubość filmu paliwowego w przewodzie dolotowym podczas symulacji zasilania benzyną i biopaliwem E85 dla prędkości obrotowej silnika 2900 obr/min i ciśnienia w przewodzie dolotowym $85 \mathrm{kPa}$

$\mathrm{Pb} 95$

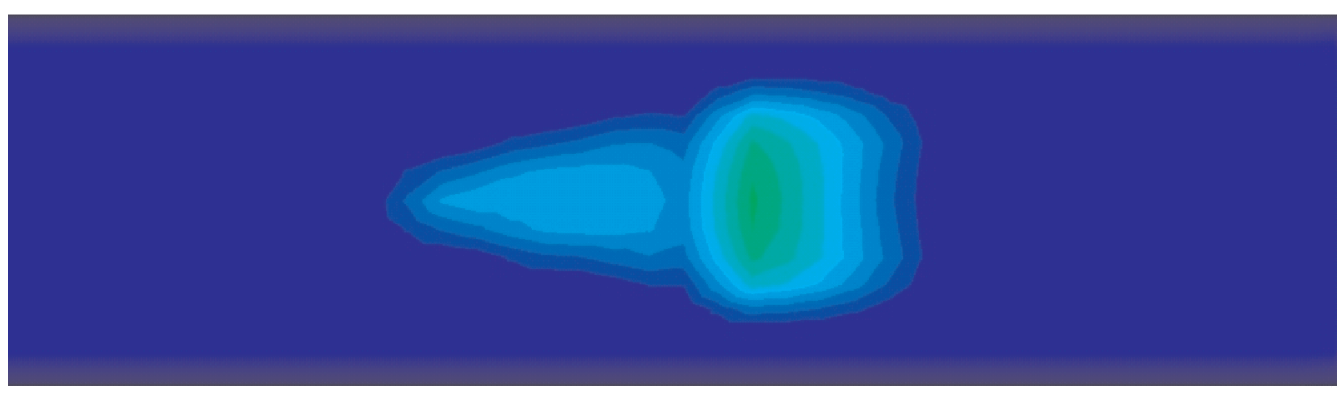

E85
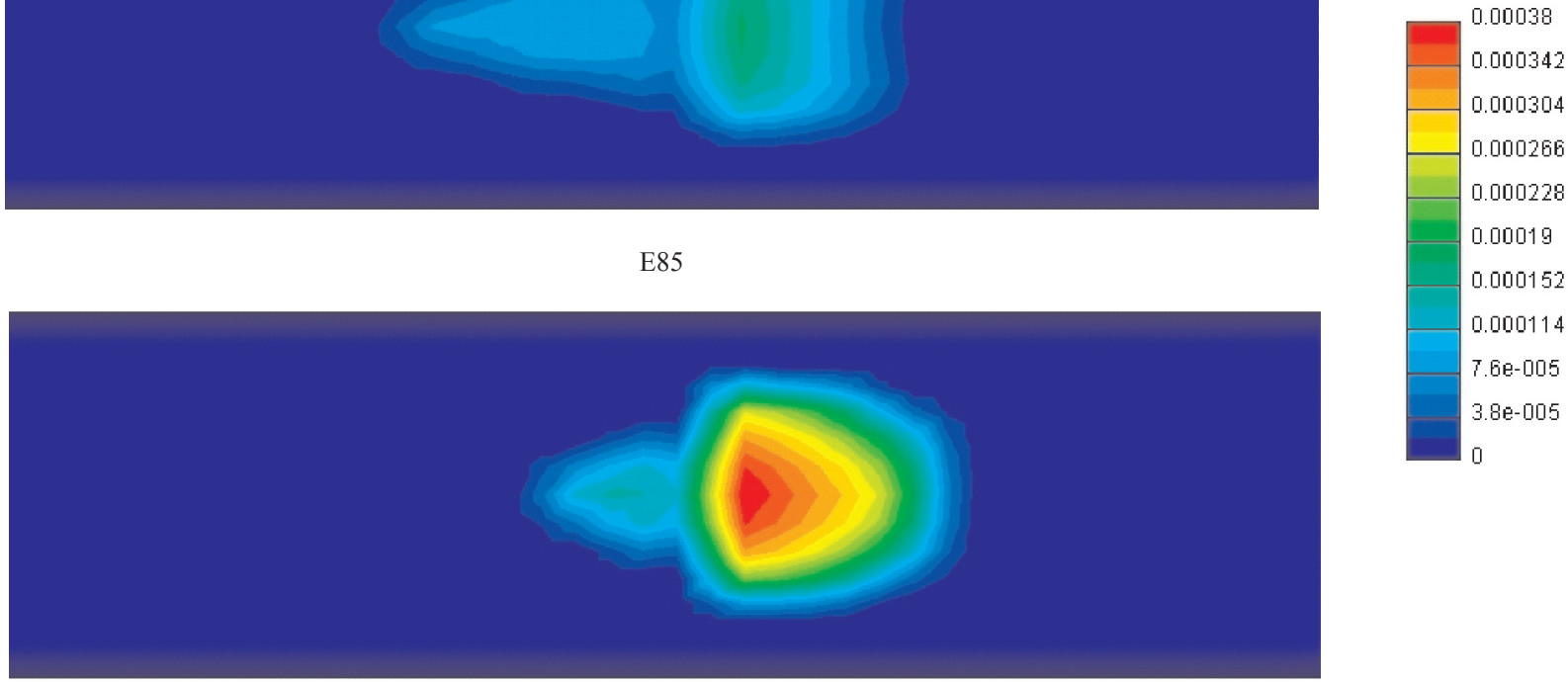

Fig. 9. Distribution and thickness of the fuel film in the intake pipe during the simulation of the feeding of gasoline and E85 biofuel for the engine speed of $3900 \mathrm{rpm}$ and the pressure of $45 \mathrm{kPa}$ in the intake pipe

Rys. 9. Rozkład i grubość filmu paliwowego w przewodzie dolotowym podczas symulacji zasilania benzyna i biopaliwem E85 dla prędkości obrotowej silnika 3900 obr/min i ciśnienia w przewodzie dolotowym $45 \mathrm{kPa}$ 

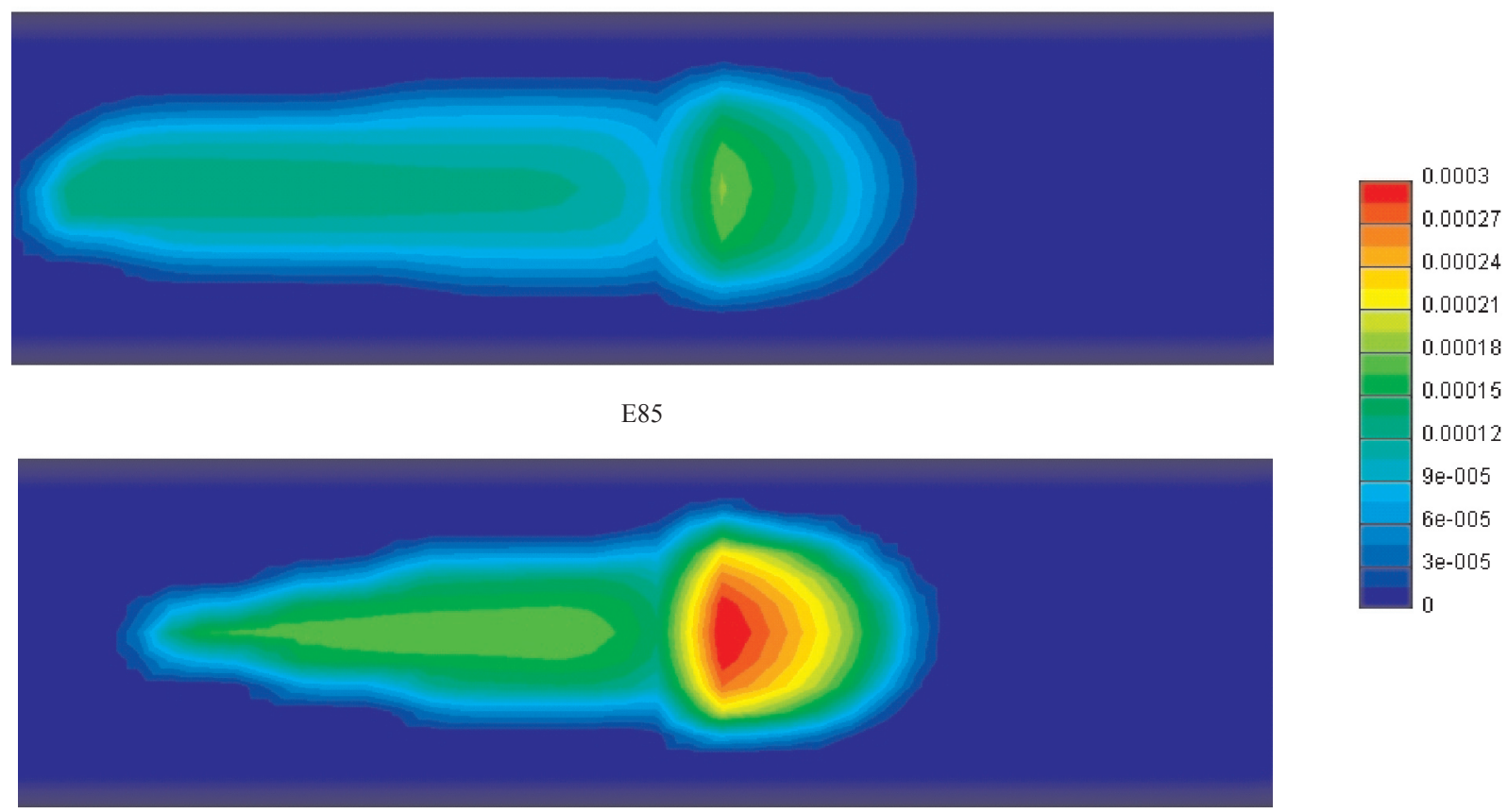

Fig. 10. Distribution and thickness of the fuel film in the intake pipe during the simulation of the feeding of gasoline and E85 biofuel for the engine speed of $3900 \mathrm{rpm}$ and the pressure of $85 \mathrm{kPa}$ in the intake pipe

Rys. 10. Rozkład i grubość filmu paliwowego w przewodzie dolotowym podczas symulacji zasilania benzyna i biopaliwem E85 dla prędkości obrotowej silnika 3900 obr/min i ciśnienia w przewodzie dolotowym $85 \mathrm{kPa}$

The fuel film surface assumes a parabolic shape (Fig. 3 -10). The maximum thickness of the film is found in the place where the fuel is fed into the pipe. With an increase of the distance from the point of fuel injection the film is spilled gradually decreasing its concentration. The film thickness for E85 fuel assumes up to several times the value of the thickness of the gasoline film. Increase of the mass

Table 1. Results of simulation tests of the fuel film thickness

Tabela 1. Wyniki badań symulacyjnych grubości filmu paliwowego

\begin{tabular}{|c|c|c|c|c|}
\hline $\mathrm{n}[\mathrm{rpm}] /$ obr/min & $\mathrm{p}_{\mathrm{b}}[\mathrm{kPa}]$ & $\mathrm{g}_{\mathrm{fPb}}[\mathrm{mm}]$ & $\mathrm{g}_{\text {fE8 }}[\mathrm{mm}]$ & $\mathrm{k}_{\mathrm{g}}[-]$ \\
\hline 1500 & 65 & 0.20400 & 0.38713 & 1.8977 \\
\hline \multirow{2}{*}{1900} & 45 & 0.16512 & 0.41193 & 2.4947 \\
\cline { 2 - 5 } & 85 & 0.24125 & 0.40142 & 1.6639 \\
\hline \multirow{3}{*}{2900} & 37 & 0.15494 & 0.43686 & 2.8195 \\
\cline { 2 - 5 } & 65 & 0.21581 & 0.37677 & 1.7458 \\
\cline { 2 - 5 } & 85 & 0.22006 & 0.35587 & 1.6172 \\
\hline \multirow{3}{*}{3900} & 45 & 0.17504 & 0.38418 & 2.1948 \\
\cline { 2 - 5 } & 85 & 0.18284 & 0.30662 & 1.6770 \\
\hline
\end{tabular}

airflow causes longitudinal stretching of the fuel film surface. Biofuel is characterized by much less intense stretching of these fragments as compared to gasoline. An increase in the mass stream of airflow results from an increase in the engine speed and an increase in the intake pipe pressure (increase of air density).

The results presented in Table 1 allow determining of the distribution and maximum thickness of the fuel film in the
Powierzchnia filmu paliwowego przyjmuje kształt paraboliczny (rys. 3 - 10). Maksymalna grubość filmu występuje w miejscu podawania paliwa do przewodu. Wraz ze zwiększaniem się odległości od punktu wtryskiwania paliwa film ulega rozlewaniu się, stopniowo zmniejszając swoją koncentrację. Grubość filmu dla paliwa E85 przyjmuje nawet kilkukrotną wartość grubości filmu benzynowego. Zwiększanie masowego strumienia przepływu powietrza wywołuje wzdłużne rozciągnie powierzchni filmu paliwa. Biopaliwo charakteryzuje się o wiele mniejszą intensywnością rozciągania takich fragmentów w porównaniu $\mathrm{z}$ benzyną. Zwiększanie masowego strumienia przepływu powietrza jest skutkiem zwiększenia prędkości obrotowej wału korbowego oraz zwiększenia ciśnienia w przewodzie dolotowym (zwiększenia gęstości powietrza).

Przedstawione w tabeli 1 wyniki pozwalają na określenie rozkładu i maksymalnej grubości filmu paliwowego w przewodzie dolotowym. Zaobserwowano, że największe różnice $\mathrm{w}$ grubości filmu paliwowego pomiędzy benzyną $\mathrm{Pb} 95$ a biopaliwem E85 występują w zakresie małych obciążeń silnika. Współczynnik kg wyraża względne zwiększenie masy filmu paliwowego E85 w stosunku do benzyny.

Po wtrysku benzyny dla danej prędkości obrotowej silnika grubość filmu paliwowego wzrastała wraz ze wzrostem ciśnienia w przewodzie dolotowym. Przy zastosowaniu paliwa etanolowego tendencja ta ma charakter odwrotny i grubość filmu maleje wraz ze wzrostem ciśnienia. $\mathrm{Na}$ rysunku 11 przedstawiono charakterystykę współczynni- 


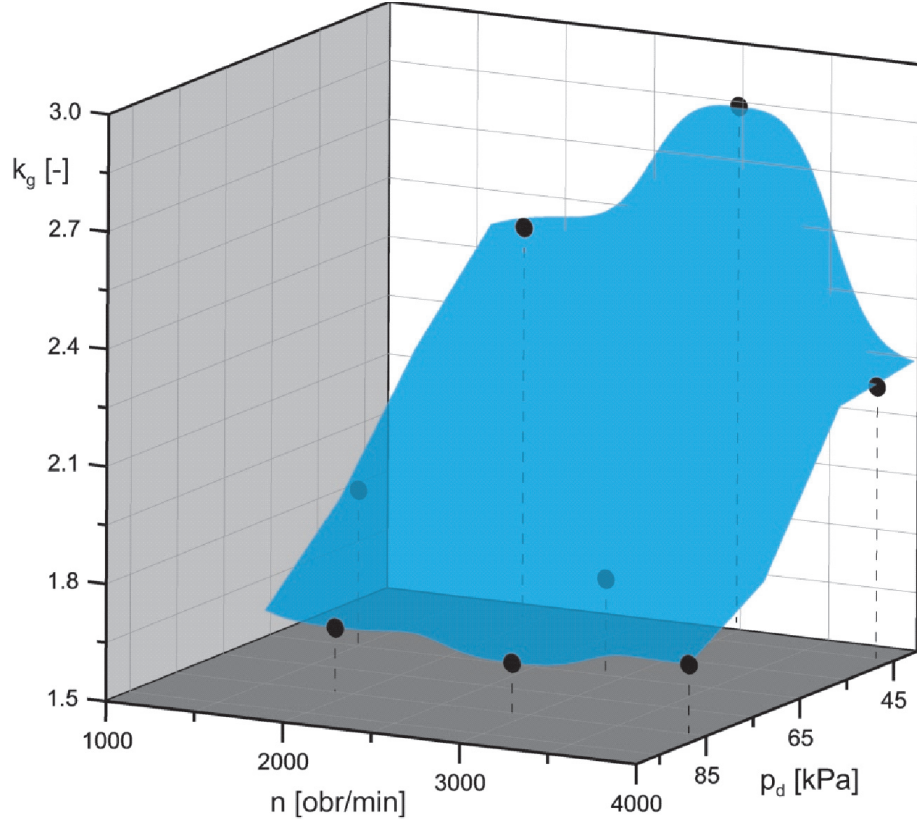

Fig. 11. Characteristics of $\mathrm{k}_{\mathrm{g}}$ coefficient of proportionality of the fuel film thickness

Rys. 11. Charakterystyka współczynnika proporcjonalności grubości filmu $k_{g}$

intake pipe. It has been observed that the greatest differences in the fuel film thickness between $\mathrm{Pb} 95$ and E85 biofuel are observed within the range of small engine loads. $\mathrm{kg}$ coefficient expresses a relative increase of the mass of the E85 fuel film as compared to gasoline.

Following the injection of gasoline for a given engine speed, the fuel film thickness increased with an increase of the pressure in the intake pipe. When using ethanol, this trend was contrary and the film thickness decreased with an increase of the pressure. Figure 11 presents characteristics of $\mathrm{kg}$ coefficient of proportionality of the fuel film thickness in the intake pipe.

\section{Conclusions}

The obtained simulation test results allowed extending the knowledge on the processes of fuel-air mixture formation taking place when feeding gasoline and a mixture of gasoline and E85 ethanol to a spark ignition engine. It has been proved that the engine speed and the pressure in the intake system have effects upon the intensity of formation and the thickness of the fuel film following a replacement of gasoline with ethanol. The fuel film thickness for E85 is at times several times greater than that of gasoline. The reasons for the significant influence of both the tested factors include changed time courses of such phenomena as development and raising of the injected fuel spray by the flowing air and sedimentation of fuel on the intake pipe walls and, in particular, changes in the area and thickness of the fuel film.

The obtained simulation test results indicate a usefulness of the testing method used for the analysis of the phenomena occurring in the engine intake system following the injection of fuel without interference with the system. The said results also reduce the testing time considerably. ka proporcjonalności grubości filmu paliwowego $\mathrm{k}_{\mathrm{g}}$ w przewodzie dolotowym.

\section{Podsumowanie}

Otrzymane wyniki z badań symulacyjnych pozwoliły rozszerzyć wiedzę o procesach tworzenia mieszanki paliwowo-powietrznej, zachodzących podczas zasilania silnika o zapłonie iskrowym benzyną oraz mieszanką benzyny i alkoholu etylowego E85. Wykazano, że istnieje wpływ prędkości obrotowej wału korbowego silnika i ciśnienia w układzie dolotowym na intensywność powstawania i grubość filmu paliwowego po zastąpieniu benzyny alkoholem etylowym. Grubość filmu paliwowego dla paliwa E85 przyjmuje niekiedy nawet kilkukrotną wartość grubości filmu paliwowego dla benzyny. Przyczynami istotnego wpływu obu czynników badawczych są zmienione czasowe przebiegi takich zjawisk, jak: rozwój i unoszenie strugi wtryskiwanego paliwa przez przepływające powietrze oraz osiadanie paliwa na ściankach przewodu dolotowego, a zwłaszcza zmian pola powierzchni i grubości filmu paliwowego.

Uzyskane wyniki z badań symulacyjnych wskazują na przydatność zastosowanej metody badawczej do analiz zjawisk, jakie zachodzą w układzie dolotowym silnika po wtrysku paliwa bez ingerencji w układ i znacząco skracają czas badań.

Paper reviewed/Artykuł recenzowany

\section{Bibliography/Literatura}

[1] AVL FIRE, Methodology.

[2] Guzzella L., Onder C. H.: Introduction to Modeling and Control of Internal Combustion Engine Systems. Springer-Verlag Berlin Heidelberg 2010.

[3] Locatelli M.: Modeling and Compensation of the Fuel Path Dynamics of a Spark Ignited Engine. Doctoral Thesis, Swiss Federal Institute of Technology, Zurich 2004.

[4] Stiesch G.: Modeling Engine Spray and Combustion Processes. Springer-Verlag Berlin, Heidelberg 2003.

Marcin Szlachetka, MSc., MEng. - postgraduate in the Faculty of Mechanical Engineering at the Lublin University of Technology.

Mgr inż. Marcin Szlachetka - doktorant na Wydziale Mechanicznym Politechniki Lubelskiej.

e-mail:m.szlachetka@pollub.pl

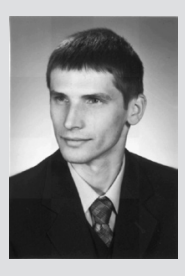

Prof. Mirosław Wendeker, DSc., DEng. - professor in the Faculty of Mechanical Engineering at Lublin University of Technology.

Prof. dr hab. inż. Mirostaw Wendeker-profesor na Wydziale Mechanicznym Politechniki Lubelskiej. e-mail:m.wendeker@pollub.pl

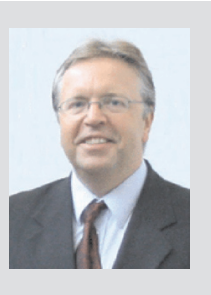

